\title{
INDUSTRIES OF ANGKOR PROJECT: PRELIMINARY INVESTIGATION OF IRON PRODUCTION AT BOENG KROAM, PREAH KHAN OF KOMPONG SVAY
}

\author{
Mitch Hendrickson ${ }^{1}$, T. O. Pryce ${ }^{2}$, Till Sonnemann ${ }^{3}$, Kaseka Phon ${ }^{4}$, Quan Hua ${ }^{5}$ and Chan \\ Sovichetra $^{6}$

\begin{abstract}
${ }^{1}$ Department of Anthropology, University of Illinois at Chicago, ${ }^{2}$ UMR7055 Prétech \& UMR 3685 NIMBE, French National Centre for Scientific Research, ${ }^{3}$ Institute for Archaeology, Heritage Sciences and Art History, Otto-Friedrich-University of Bamberg, ${ }^{4}$ Royal Academy of Cambodia, ${ }^{5}$ Institute for Environmental Research, Australian Nuclear Science and Technology Organisation, ${ }^{6}$ Department of Land Management Urban Planning Construction and Cadastral.
\end{abstract}

\begin{abstract}
The Industries of Angkor Project (INDAP) is the first intensive investigation into the history and role of iron production at Preah Khan of Kompong Svay (Preah Khan), the largest regional enclosure complex built by the Angkorian Khmer (9th to 15th c. CE) in Cambodia. We present the initial multidisciplinary research of the primary iron smelting sites located on Boeng Kroam, a large reservoir located north of Preah Khan's central temple complex. Ground-penetrating radar surveys and excavation at Location 1, a slag concentration on top of the reservoir bank, revealed that it is a deposit of metallurgical waste from a nearby furnace. Multiple radiocarbon dates from Location 1 indicate that the smelting activities took place in the early 15th century during the time of Angkor's ultimate collapse as the political centre of the Khmer world. This indicates a re-use of spaces by iron workers after the primary occupation of Preah Khan between the 11th and 13th centuries.
\end{abstract}

\section{BACKGROUND}

At its peak between the $11^{\text {th }}$ to $13^{\text {th }}$ centuries CE, the Khmer Empire stretched across large swathes of mainland Southeast Asia. Along its great roadways this empire established large provincial administrative centres that may have played a critical role in ensuring access to resources and products to supply the capital, Angkor, and the expansionism of its kings. A direct implication is that the growth and decline of Angkor is traceable through an evaluation of these regional centres, which may also have acted as specialised production centres. More broadly, investigating the development and effect of industrial activities in medieval Southeast Asia will set precedents for the study of states and empires globally.

Preah Khan of Kompong Svay (Preah Khan) ${ }^{1}$, is one of the most enigmatic provincial centres built in the Angkorian period (Figure 1). Boasting the largest enclosure complex in mainland Southeast Asia $\left(23 \mathrm{~km}^{2}\right)$, Preah Khan is the only known Khmer settlement to contain evidence of intensive industrial activities, specifically the smelting of iron. The geographic position of Preah Khan also supports its role in the production and distribution of iron (Hendrickson 2011; see discussion in Hendrickson and Evans 2015). The settlement is located close to the largest iron oxide source in Cambodia, Phnom Dek, and at the junction of two major communication routes: the Staung River and the formalised Khmer road system that is fitted with masonry resthouse temples and bridges. These routes provide direct access not only to Angkor but to numerous Khmer centres connected to the Tonle Sap and Mekong via the navigable water systems. Difficult access to Preah Khan had contributed to the limited of archaeological research at this important site and today its history has been based solely on stylistic dating of temple architecture and limited inscription evidence. Together these sources indicate substantial Angkorian activity at the site between the $11^{\text {th }}$ to $13^{\text {th }}$ centuries CE. However, given its size and potential economic importance it is extremely likely that occupation both pre- and post-dates this period.

\section{PAST RESEARCH AT PREAH KHAN OF KOMPONG SVAY}

Previous investigations at Preah Khan have concentrated on three themes: documenting architectural features, estab-

\footnotetext{
${ }^{1}$ Both Preah Khan of Kompong Svay and Bakan are used to describe the central temple complex, which consists of the buildings within the first to third masonry walls, as well as the vast fourth earthen enclosure walls that demarcate the edge of the settlement.
} 


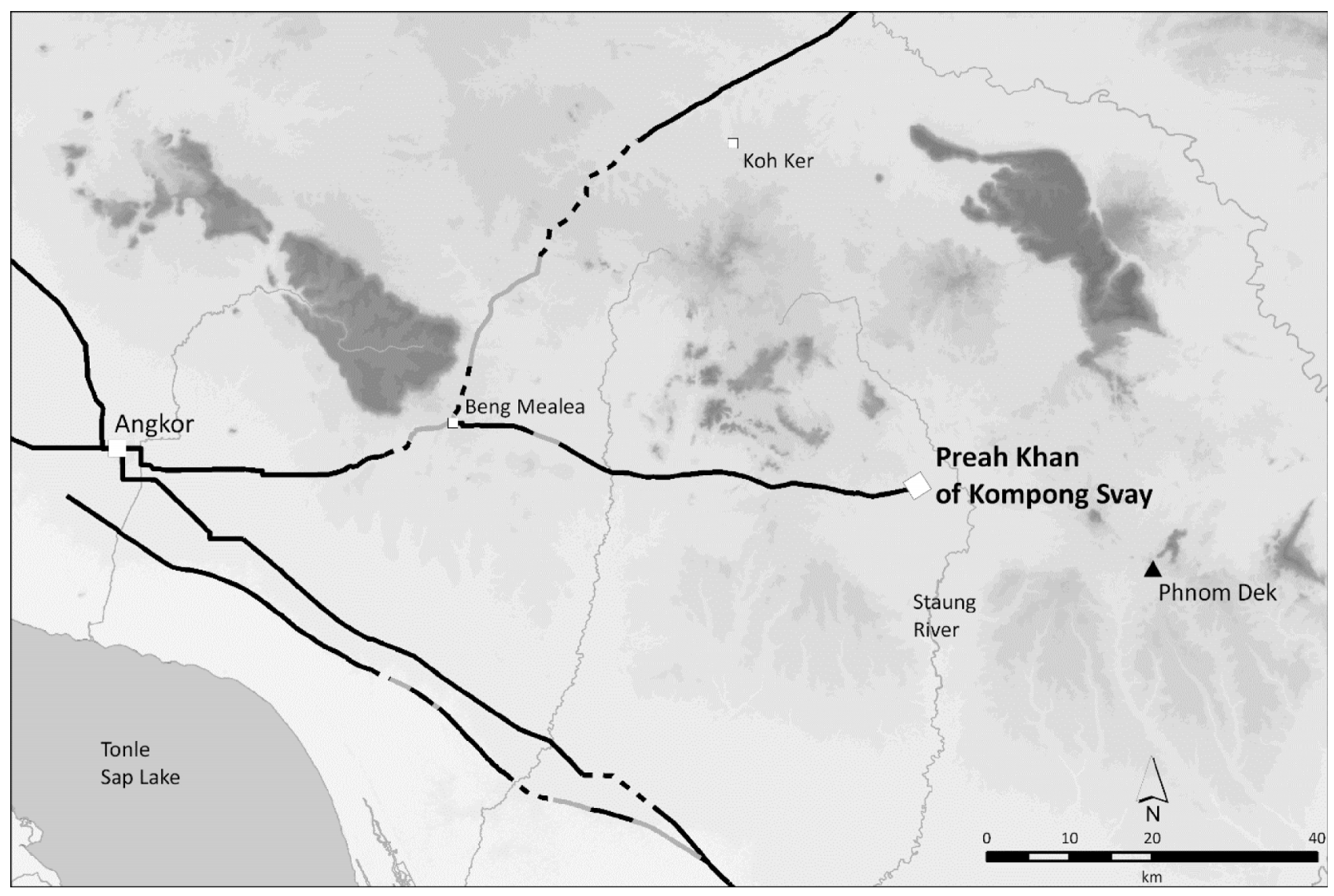

Figure 1. Map showing position of Preah Khan of Kompong Svay and its relationship to Angkor along the East road.

lishing temple chronology through architectural and inscription-based information, and debating the function of the complex. The 1866 Mekong Exploration Commission (see Delaporte 1999 [1880]; Tissandier 1896:75-80) provided the first record of its temples and large water reservoirs hidden within the forests west of the Staung River. Aymonier (1900) and Lunet de Lajonquière (1902), who both completed extensive temple inventories across the French Protectorate, added further details of its masonry architecture but also noted several characteristics that distinguished Preah Khan from other Angkorian centres: the scale of construction, specifically a $25 \mathrm{~km}^{2}$ (sic) enclosure surrounding the central complex; and that the temples are aligned NE-SW, not the typical E-W associated with architecture built around Angkor (Aymonier 1900:430; Lunet de Lajonquière 1902:242). Mauger (1939) then published detailed descriptions of all architectural features and with the help of Terrasson and Goloubew's aerial reconnaissance over the complex produced the first complete map of its internal structure (Figure 2). This perspective of Preah Khan remained the cornerstone of interpretations about its settlement organization and role in Angkorian history (see Jacques and Lafond 2004:264; Phann and Chrin 2007). Completion of a new map of Preah Khan (Hendrickson and Evans 2015) highlights the unique nature of its hydraulic organization and that settlement evidence is largely concentrated around the central temple complex. The absence of village temples, mounds, ponds beyond its walls suggest that the site was an outpost rather than a centralized node within a broader Khmer setting.

Like most Angkorian centres, the chronology of Preah Khan has been solely derived from a combination of inscriptions and architectural styles. While three 'datable' inscriptions have been identified - K. $970\left(9^{\text {th }}\right.$ c. CE [Cœdès 1964]), K. 161 ( 1010 CE [Kern 1880]), K. 888 (early $14^{\text {th }}$ c. CE [Mauger 1939:212]) - only K. 161 from the Monument of the Inscription or Prasat Kat Kdei provides any significant historical details. The beautifully carved Sanskrit inscription is both a devotional text to Shiva and the Buddha and a historic document describing the rise to power of Suryavarman I (1002-1050 CE) (T.S. Maxwell, pers. comm., June 2010). Based on this date, Mauger posited that Prasat Kat Kdei was the first temple built at Preah Khan (1939:217-218). The bulk of temple construction at Preah Khan, however, is associated with either the first half of the $12^{\text {th }}$ (Angkor Wat style) and late $12^{\text {th }}$ to early $13^{\text {th }}$ c. CE (Bayon style) (Stern 1965:87-99; Cunin 2004). No radiometric dates have been obtained from any contexts and detailed investigation of ceramic assemblages has yet to be completed.

Functional interpretations of Preah Khan have focussed on the type of Buddhism depicted in the temple iconography, its use as a base for future kings of Angkor, 


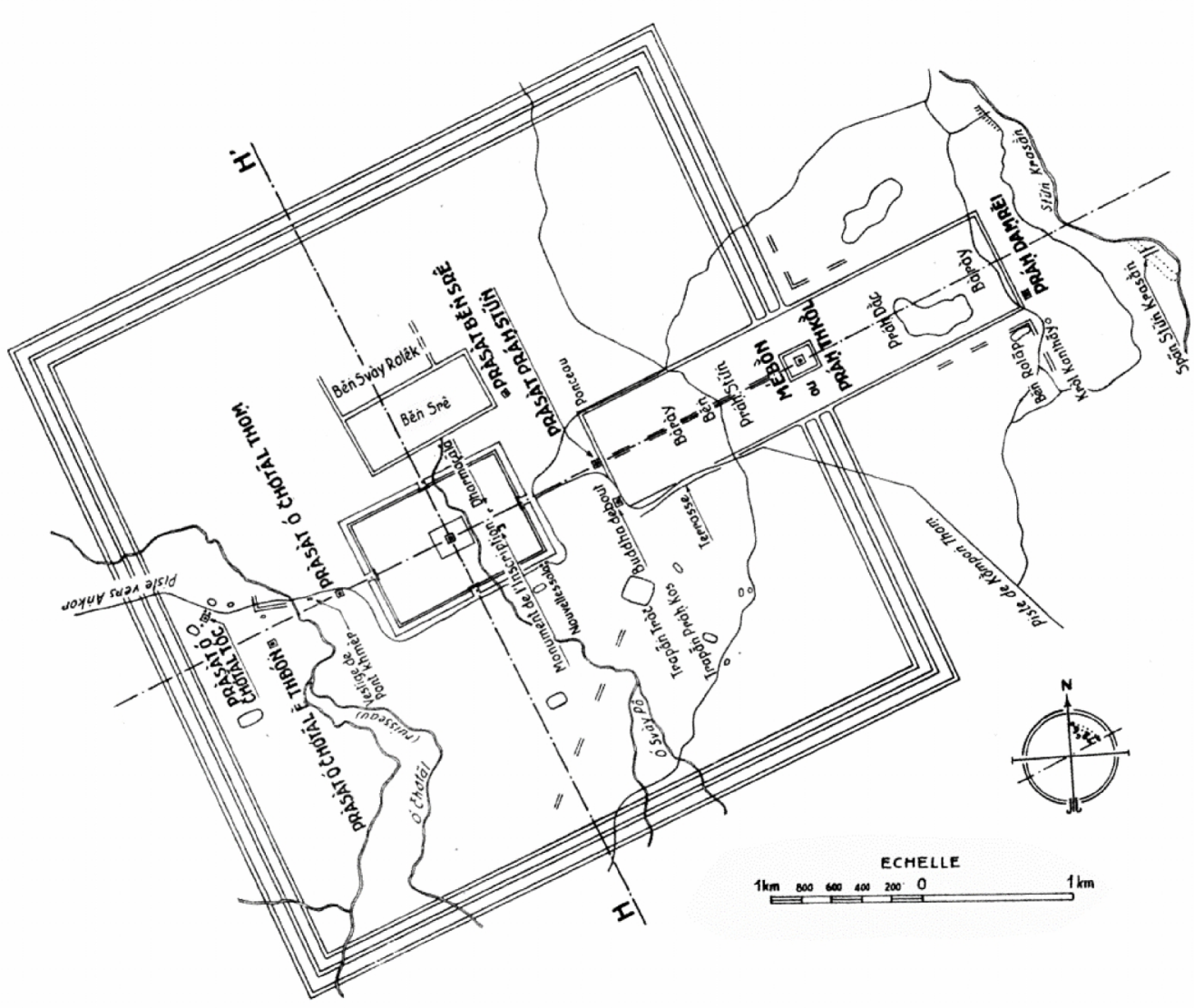

Figure 2. Original plan of Preah Khan of Kompong Svay by Mauger (1939).

and geographic explanations for its isolated position. The prevalence of Buddhist imagery has led scholars to argue for the practice of particular aspects of Tantric Buddhism (Sharrock 2009) and potentially the presence of a Crighana 'cult' (Jacques and Lafond 2004:289). These religious interpretations are intertwined with the architectural styles and the kings with whom their reigns are associated, such as Angkor Wat-Suryavarman II and Bayon-Jayavarman VII. The latter king has been variously connected to Preah Khan as his potential birthplace (see Jacques and Lafond 2004:289), early home or refuge prior to his transition to Angkor (Groslier 1973:64). It is unlikely that we will find archaeological data to verify the accuracy of these hypotheses.

More intriguing, and ultimately testable, lines of investigation are geographic explanations for Preah Khan's relatively isolated position in north central Cambodia. Groslier (1973:117) argued generally that main Khmer centres are always located on favourable river courses. The position of Preah Khan obviously took advantage of the Staung River, either for hydraulic purposes inside the complex or as a transportation route. Groslier also suggested that Preah Khan was an eastern outpost for Angkor established during the course of Khmer wars with the Cham during the $12^{\text {th }}$ century (Ibid.:257). While there are no large Khmer centres to the east of Preah Khan this argument seems extremely doubtful. The heart of Cham territories around Vijaya is over $500 \mathrm{~km}$ away and there is no evidence of a formalized road east of Preah Khan through the densely forested and rugged region leading to the Annamite mountain chain. A more local geographic explanation is the proximity of Preah Khan to the rich iron oxide sources around Phnom Dek. Despite Aymonier's (1900:430-431) discovery of slag outside the third enclosure (the Bakan) there was very little subsequent interest in documenting the extent of iron production. Over the past decade however, recent publications have shown an increased interest in the distribution of metal production sites at Preah Khan (see Jacques and Lafond 2004:259-266; Living Angkor Road Project 2008[II]:232). In fact, Jacques claimed "beyond doubt" that Preah Khan served as the heart of an industrial centre for the Khmer (2007:32). A comprehensive investigation of the scale and extent of this industry inside the enclosure walls is now required.

\section{THE INDUSTRIES OF ANGKOR PROJECT}

The Industries of Angkor Project (INDAP) is a collaborative research initiative between the University of Sydney (now based at the University of Illinios at Chicago) and the Ministry of Culture and Fine Arts and partnerships with the École française d'Extrême-Orient, the Australian 


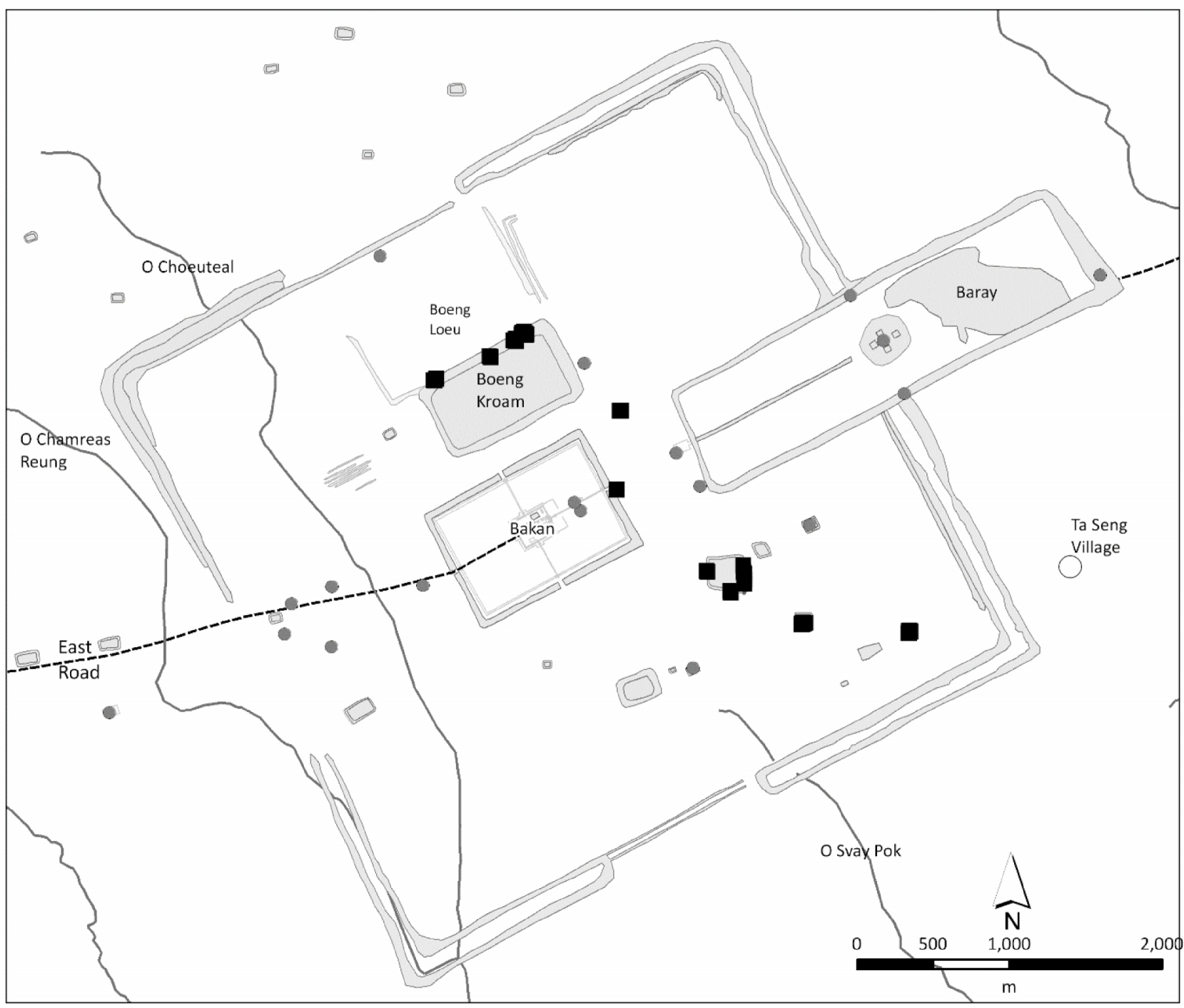

Figure 3. Distribution of iron production sites (black squares) within Preah Khan of Kompong Svay.

Nuclear Science and Technology Organisation (ANSTO), Cologne University of Applied Sciences, University of Oxford, and the Royal Academy of Cambodia. INDAP represents the first systematic and rigorous investigation of the stages of procurement, production and distribution of industrial products (iron, temples) and the environmental impact of these activities at a regional Khmer centre. Investigating the stages of industrial activities will provide a new picture of how these centres functioned - from an economic and political point of view - within the broader framework of an empire that incorporated most of mainland Southeast Asia. Combining results from the analysis of two different industries simultaneously enables broader ranges of interpretation that will be used to address the following issues: 1) identify the nature and extent of production of industrial materials and the human

${ }^{2}$ An alternative transliteration of the site name is Boeng Kraom (Thuy Danel, personal communication, July 2015). settlement that would have supported these activities within the site; 2) discover when the Preah Khan was founded and if it was, from its foundation, an industrial settlement; 3) determine if the location of Preah Khan and its industrial capacity were linked directly to the demand for iron at Angkor; and, 4) reveal precisely when Preah Khan and its industries collapsed. More directly, this investigation will assess whether Preah Khan resembled other Angkorian urban centres or was a unique, specialised industrial outpost of the empire. Ultimately, this research will provide new information on the coalescence, operation and eventual demise of one of the World's great empires. This paper will present initial research on the metal production sites identified at Boeng Kroam ${ }^{2}$ (also known as Boeng Sre), the second-largest water reservoir inside the walls of Preah Khan. 


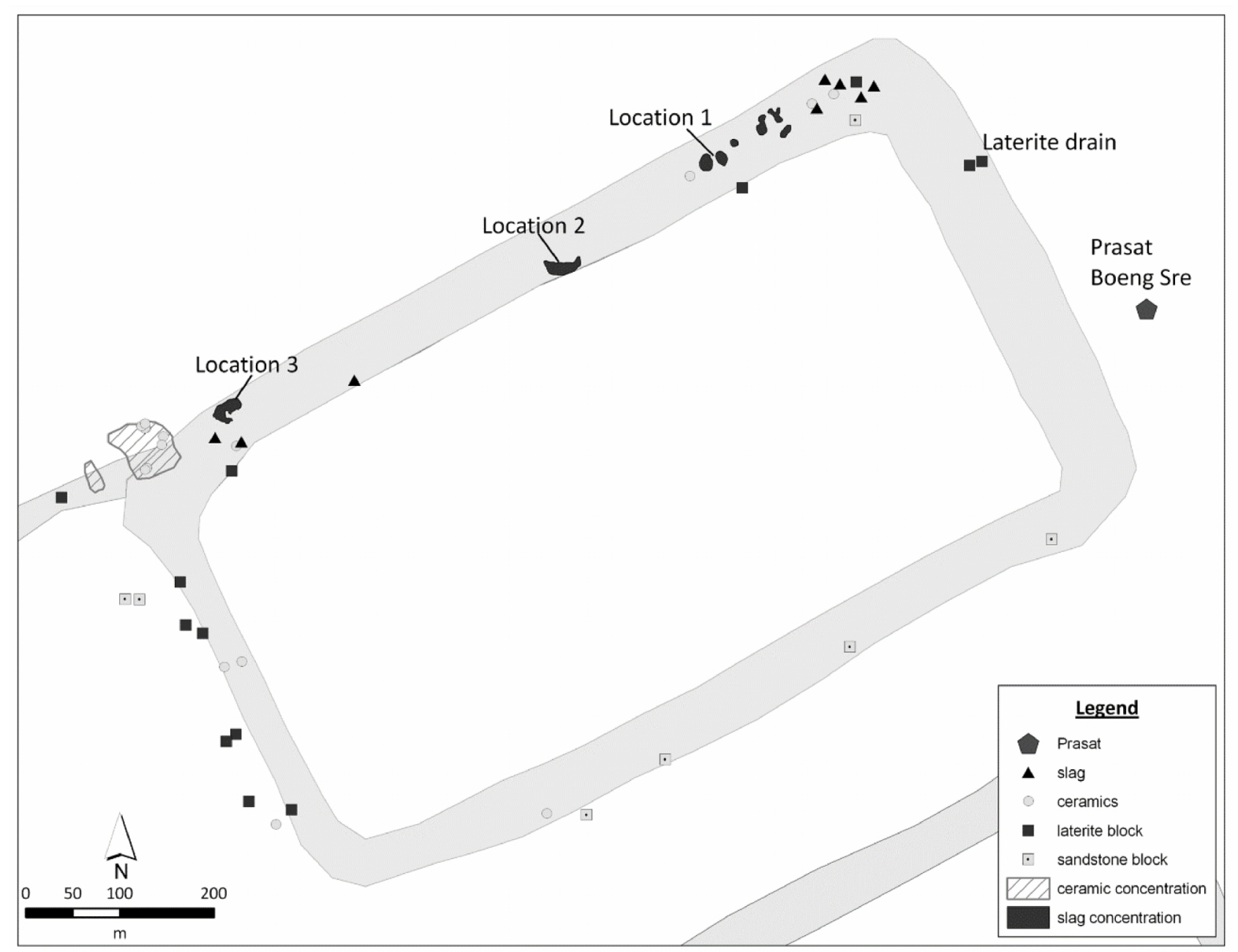

Figure 4. Cultural features identified on the banks of Boeng Kroam.

\section{EVIDENCE OF IRON PRODUCTION AT PREAH KHAN}

Fieldwork in 2009 identified both iron artefacts and iron production sites within Preah Khan. Iron artefacts are rarely found due to issues of preservation and ease of recycling. Architectural crampons concealed between temple blocks remain one of the last in situ forms of iron from this period, although many crampons have been looted at numerous temple sites in the Khmer world (Cunin 2007:254). At Preah Khan a single crampon was collected from Prasat L, a late 12 th century sandstone addition within the second enclosure. The I-shaped crampon is composed of three pieces welded together and is in a remarkably good state of preservation. Given that it was exposed to the elements its condition suggests that the ferrous alloy may have some corrosion-resistant properties, be they naturally derived from the ore or deliberately engineered. Based on other crampons found in the Angkor region it shares morphological similarities to examples recovered from other late 12 th century temples such as Preah Khan.

Iron production sites were found at many locations within Preah Khan. Characterised by dense surface concentrations of slag (furnace, tap, and smithing hearth morphologies [see Pryce and Natapintu 2009]), ceramic tuyères, clay furnace wall fragments, gangue minerals, and iron oxide ore are much more common between the third and fourth enclosure walls. A total of 15 sites have been identified, including the one initially described by Aymonier outside the moat of the third Gopura East (G3ES/STK-01) (Figure 3). The greatest density of metallurgical activity was found on the banks of Boeng Kroam. These sites will be the main focus of the present discussion.

\section{Boeng Kroam}

Boeng Kroam, also known as Beng Sre, is the second largest reservoir in Preah Khan. This rectangular reservoir shares the characteristic NE/SW orientation of most Angkorian construction within the settlement and has internal dimensions of $870 \mathrm{~m}$ by $440 \mathrm{~m}$. Topographic survey revealed that the interior of Boeng Kroam is 2 to 2.5 $\mathrm{m}$ lower than the exterior ground surface, which indicates that the banks were constructed by excavating and depositing earth from inside of the reservoir. The north bank of Boeng Kroam also acts as the southern wall of what is known locally as Boeng Loeu, a three-sided 
structure that may have held water in the past but is currently dry. The interior of Boeng Kroam was dry during the 2007 survey, but today the reservoir is filled with water as a result of the recent addition of culverts built into the NW and SE corners. During the 2009 field seasons, ground survey, geophysical prospection and excavation were conducted at this site with specific focus on identifying the range of sites associated with this infrastructure.

\section{Ground Survey}

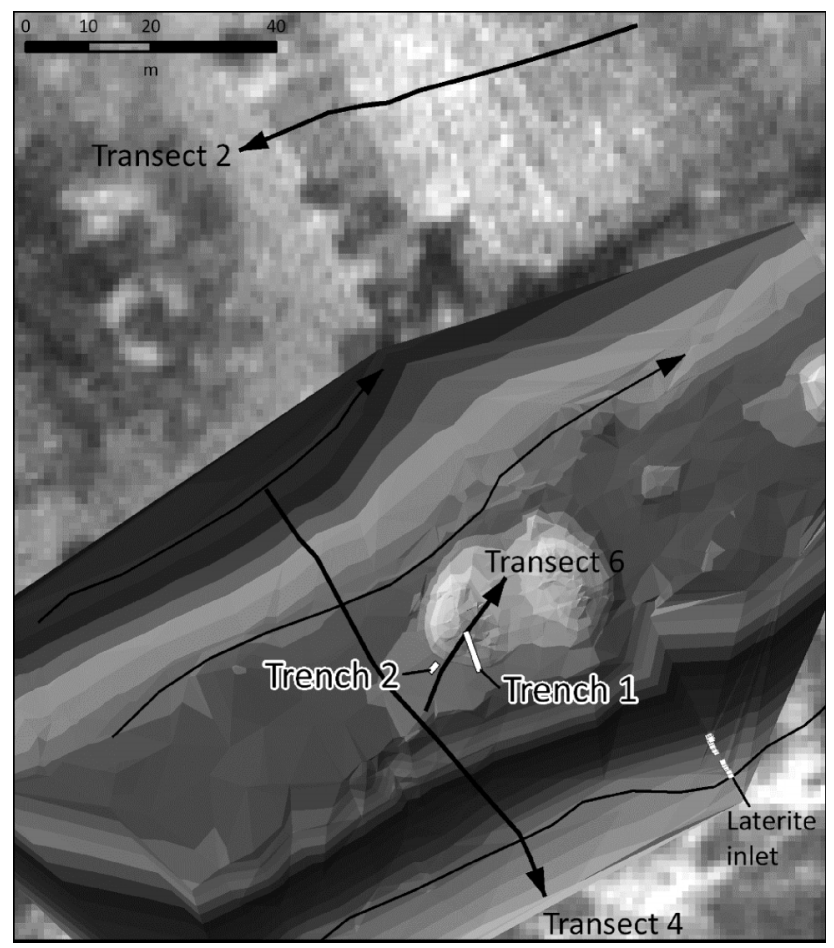

Figure 5. Topographic map of Boeng Kroam Location 1 showing locations of GPR transects and trenches. (background image OrbView-3 courtesy of GeoEye Foundation).

Surveys conducted at Boeng Kroam show marked diversity of cultural activities on each bank (Figure 4). The north bank contains the greatest quantity of non-architectural archaeological remains including a large ceramic concentration and numerous metal production loci. Small ceramic scatters were noted at several locations but the largest was identified near the west corner covering an area approximately 50 by $60 \mathrm{~m}$ across the top and down the external side of the bank. The assemblage included local brown and green glaze and earthenware types and imported Chinese wares. Among the earthenware ceramic sample were leg fragments of a stove indicating domestic activities in the area. Ceramics were also present within the bank during the construction of the new culvert at the northwest corner of Boeng Kroam. Local workers indicated that a substantial amount of pottery was unearthed during this work and redeposited onto the north bank of the reservoir. At the east corner are comparable Khmer glazed wares as well as terracotta roof tiles characterised by a pale coarse paste. The presence of utilitarian and architectural ceramics indicates some form of settlement along the north bank from at least the 11th to 14 th centuries.

The bulk of the cultural material identified on the north bank is related to iron production. Slag concentrations with and without visible technical ceramics (e.g., tuyères, fragments of furnace wall) appear with the greatest density towards the eastern half of the bank. The position and size of these concentrations vary and three different relationships with the bank (mound, inside, external face) are identified at Locations 1-3.

Location 1 (Figure 5) comprises two slag mounds situated on top of the embankment. These mounds are oriented perpendicular to the line of the bank and are covered with slag and numerous fragments of technical ceramic, specifically tuyères. Mound $\mathrm{A}$ is approximately $18 \mathrm{~m}$ long, $16 \mathrm{~m}$ wide, and $2 \mathrm{~m}$ in height and has a volume calculated to be $112 \mathrm{~m} 3$. Mound B is $23 \mathrm{~m}$ long, $14.5 \mathrm{~m}$ wide, and $2 \mathrm{~m}$ in height with an estimated volume of $103 \mathrm{~m} 3$. To the east of Mound B is a small depression continuing along the inside wall of Boeng Kroam. At the base of the embankment is an $8 \mathrm{~m}$ long feature composed of a single course of laterite blocks. The proximity and orientation of this feature to the gully in the embankment suggest it may be part of an inlet for the reservoir.

Location 2 is a large slag concentration within the interior face of the north bank. Slag appears approximately $2 \mathrm{~m}$ before the embankment edge and continues to the bottom of the internal face. The slope is a continuous deposit of metal production waste extending approximately $5 \mathrm{~m}$ vertically and $42 \mathrm{~m}$ laterally and is bounded by eroding gullies that demarcate the edge of the cultural material. Based on this topography and presuming that the production waste continues to the base of the bank, Location 2 has an estimated volume of $1811 \mathrm{~m} 3$.

Location 3 is a low-lying slag concentration situated on the external edge of the north bank. Though not as distinct as at Location 1, three areas of iron production are visible from the topographic survey. Two of these concentrations have a maximum relief of $50 \mathrm{~cm}$ and are bounded by a sudden drop-off to the north.

Evidence of iron production was not identified on the other banks of Boeng Kroam. On the west, cultural material was limited to individual blocks of laterite and sandstone and few sherds of glazed ceramics on the interior and exterior edges of bank. Among the masonry blocks are two carved sandstone columns from a temple doorframe, however there is no indication that a larger structure was erected in the immediate vicinity. Brown glaze Khmer ceramics were also identified near a looter's pit but there is no obvious settlement structure or mound.

The south bank was only partially surveyed due to vegetation cover and the subsequent risk of mines and unexploded ordinance (UXO). The most significant cultural feature is a mound with sandstone and laterite blocks and ceramics. Oriented along the same axis as the north gate of Bakan, this site may have been part of infrastructure connecting the main temple complex with the reservoir. The east bank lacks any ceramic evidence but 


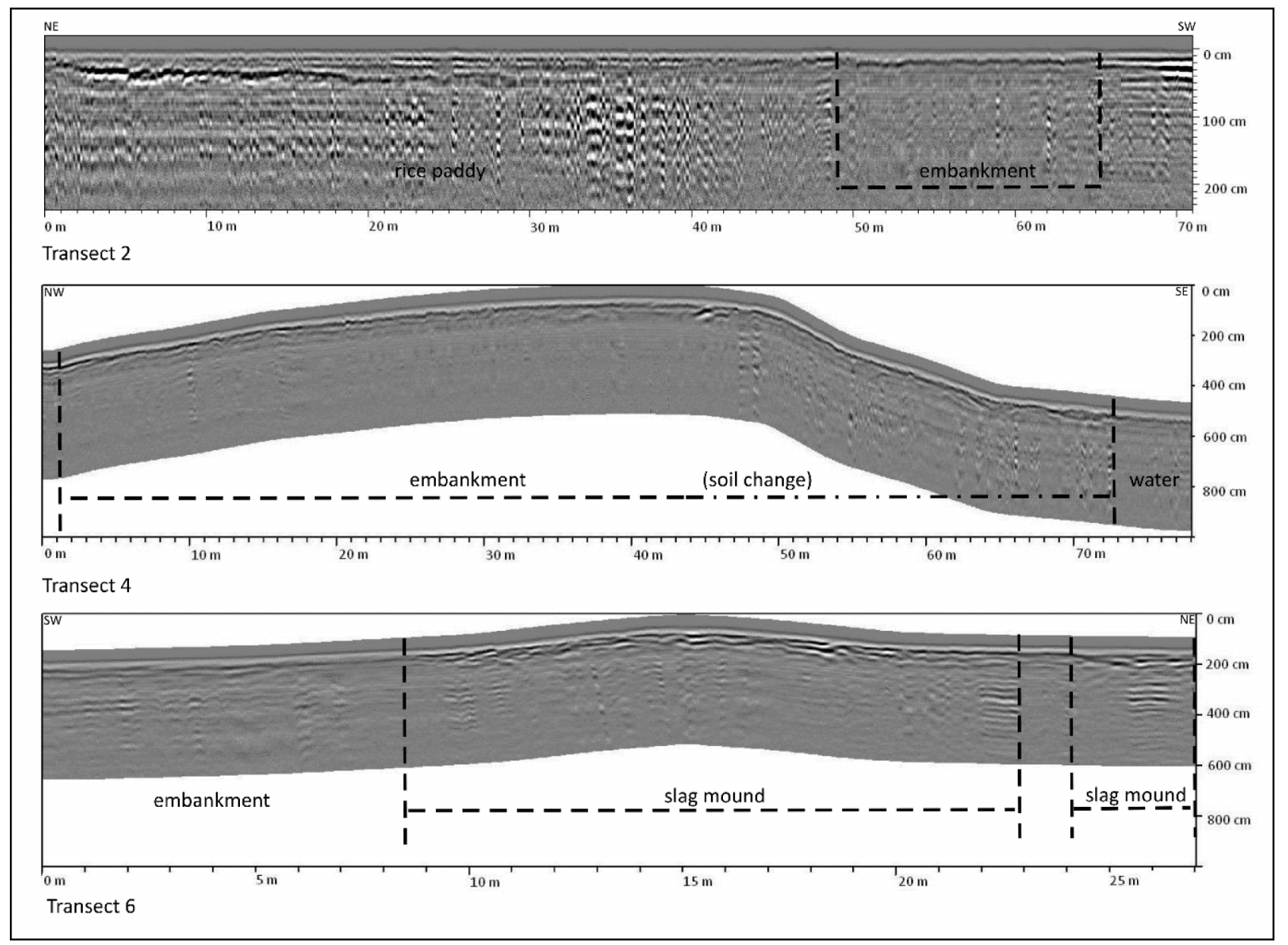

Figure 6a-c. GPR transects at Boeng Kroam Location 1 showing signal responses indicative of cultural features.

is noteworthy because of its association with two substantial masonry structures.

A laterite 'drain' reported by Christophe Pottier (pers. comm., November 2006) extends approximately $15 \mathrm{~m}$ through the top of the bank and consists of at least 3 courses of stone. Carved into the second course of both the internal and external sides are sets of three round holes. The holes appear to be part of a drain used to prevent flooding over the bank. If this is the case, their high position up the bank demonstrates that the reservoir once contained substantial amounts of water. Further survey is required to determine whether this structure functioned as a formal inlet or outlet for the reservoir. The second structure is Prasat Boeng Sre (Prasat Beng Srè) located ca. $70 \mathrm{~m}$ east of the bank, and the only temple in the vicinity of Boeng Kroam. The dating of this small laterite complex is unclear but its position and comparable orientation to the reservoir indicates a temporal, or at least spatial, relationship. Jacques (Jacques and Lafond 2004:266) has suggested that this may have been the first religious building constructed at Preah Khan, however, there is no direct evidence to support this hypothesis.

\section{Ground Penetrating Radar Survey}

Geophysical investigation using Ground Penetrating Radar (GPR) was conducted around Location 1 at Boeng Kroam to identify the subsurface extent of slag concentrations and structure of the embankment. A Malå GPR unit with a 250 $\mathrm{MHz}$ antenna was used to collect single-run data producing long-distance profiles of the subsurface across the site. This particular GPR unit is useful for identifying significant soil changes, such as buried walls or masonry and changes in geology, either caused by natural or local factors. It has an effective range of 5-6 m depending on soil type and spacing between transect lines, however it has difficulty penetrating clays and the expected maximum visible depth at around PKKS is $2 \mathrm{~m}$ below ground surface.

Six GPR transects were processed using GPR Slice software, then topographically corrected and integrated into ArcGIS 9.2. Generally, the GPR provided very shallow results however three transects (Figure 6) show clear relationships between cultural features (paddy field, embankment, slag mound) and soil structure. Transect 2 shows a clear distinction between the paddy field (to the ne) and the perpendicular embankment (to the SW) connecting to the north wall of Boeng Kroam. This transit- 


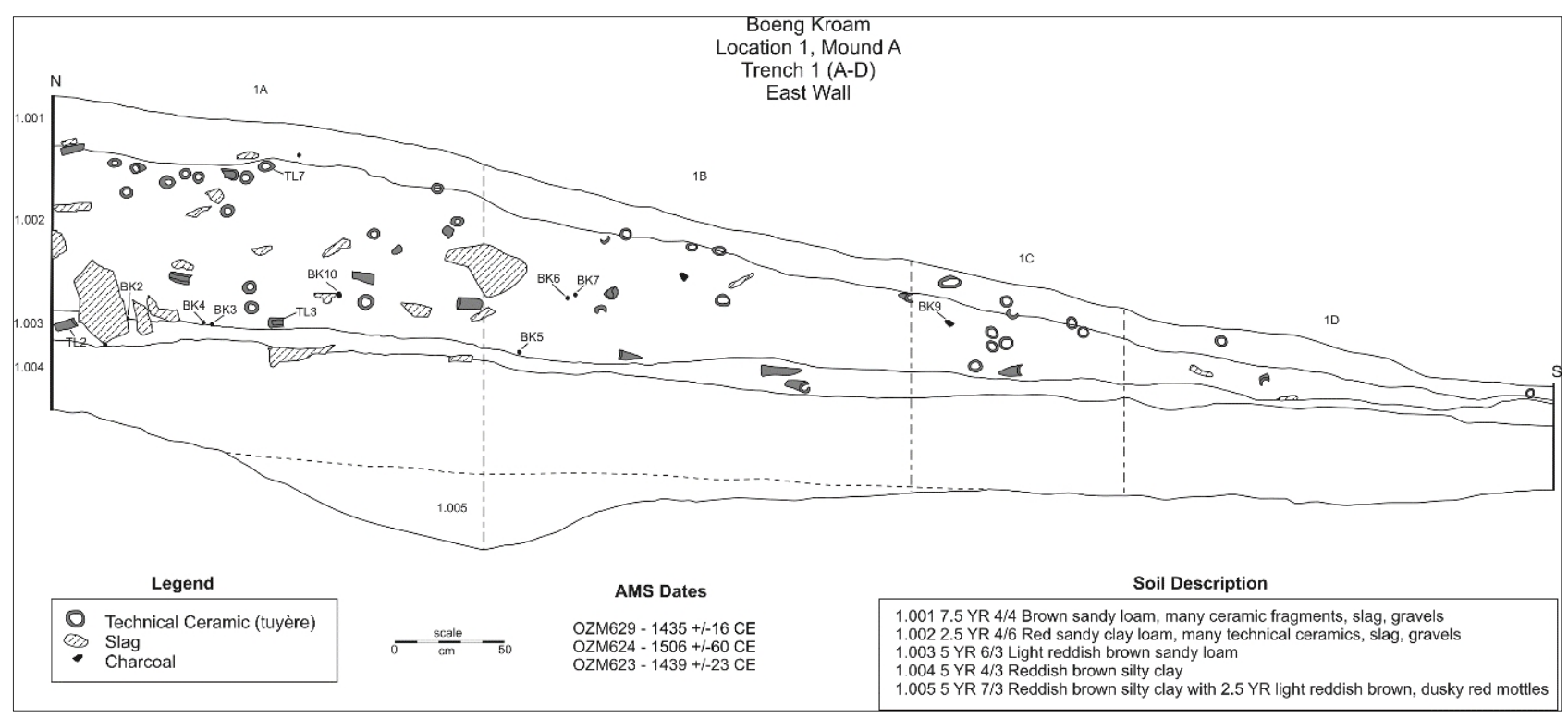

Figure 7. East wall section of Mound 1.

ion is related to a distinct soil change between these two features, likely associated with the compaction of the embankment overtop of the natural surface. Signal penetration across the Boeng Kroam embankment (Transect 4) was extremely shallow (max. $50 \mathrm{~cm}$ ) and is attributed to the hard and compact clays that constitute the upper part of the structure. A slight signal change noted on the inside of the embankment is potentially linked to the effects of water storage inside the reservoir. The presence of the laterite drain near the top of the east bank (see Figure 4) indicates that water levels may have been considerably higher than the present day. Transect 6 was placed over top of Mound A to determine its relationship with the top of Boeng Kroam. The response increases in depth with a stronger reflection that clearly defines the horizontal extent of the slag concentration. Based on this result the slag concentration is positioned on top of the embankment and is tested through excavation.

\section{Excavation of Location 1}

Two trenches were excavated at Location 1 to document the structure and chronology of the slag concentration and collect material for a laboratory-based technological reconstruction of iron production behaviours. Trench 1 was a $1 \times 7 \mathrm{~m}$ unit positioned over the southern half of Mound A. At its highest point, the mound contains ca.1.1 m of iron production material on top of the Boeng Kroam embankment (Figure 7). The industrial deposit consists of three distinct parts: an upper A Horizon layer mixed with slag and tuyères (1.001), a thick homogeneous layer of iron production material (1.002), and a burned basal layer (1.003). The embankment beneath this deposit consists of densely packed sterile clays. No evidence of in situ furnace structures was identified in any layer and it is unclear if the burned layer resulted from the deconstruction and discard of superheated furnace material. Trench 2 was positioned to the southwest of Mound A to confirm that the slag concentration superposed the embankment. By contrast with the loose structure of Trench 1, the soils in Trench 2 are dominated by hard-packed clays. Iron production waste is apparent in the upper $20 \mathrm{~cm}$, in particular toward the eastern end of the trench. Beneath this obvious cultural layer, the matrix included small sandstone fragments with an especially dense concentration identified in the southwest corner. The basal layers are densely-packed, sterile clays. The low density of iron production waste and the fact that it concentrates closest to Mound A suggest the cultural material is the product of erosion or tertiary deposition after the smelting events.

Proportions by mass of production waste (e.g., slag, tuyères, furnace wall, charcoal, minerals) were recorded in three $200 \mathrm{~kg}$ samples (see Table 1) show little variation through and across the mound. Overall, the composition and proportions for Mound A fit with globally typical ratios of pre-modern iron production contexts (i.e., slag concentrations). Both the lack of visible furnace structure and relative proportions of material indicate that Mound $\mathrm{A}$ is a secondary deposit and not the smelting site proper. The most likely location for the furnace is between Mound A and $\mathrm{B}$, however, further subsurface testing was not possible during this field season. Samples for technological analyses were only taken from Trenches 1A (1002 - 10-20 $\mathrm{cm} ; 1004-50-60 \mathrm{~cm} ; 1006-80-90 \mathrm{~cm})$ and 1D (1002 $10-20 \mathrm{~cm})$. Technological and provenancing analyses are currently being completed on slag, mineral, technical ceramic, and tuyère samples from Trench 1 . In addition to documenting the particular configuration of iron production behaviours at Boeng Kroam, these results will determine whether the iron ores used originate from Phnom Dek.

Tuyères (Figure 8) are the most common diagnostic artefact from the metallurgical assemblage. Morphometric 
Table 1. Proportions of different iron production materials in $200 \mathrm{~kg}$ samples taken from Trenches $1 \mathrm{~A}$ and 1D.

\begin{tabular}{|c|c|c|c|c|c|c|c|c|}
\hline Material & 1A 1002 & Ratio & 1A 1004 & Ratio & 1A 1006 & Ratio & 1D 1002 & Ratio \\
\hline Slag & 72 & $36 \%$ & 65 & $33 \%$ & 64 & $32 \%$ & 63.5 & $32 \%$ \\
\hline Tuyères & 17 & $9 \%$ & 20.5 & $10 \%$ & 15.5 & $8 \%$ & 14 & $7 \%$ \\
\hline Other ceramic & 6.5 & $3 \%$ & 6 & $3 \%$ & 3 & $2 \%$ & 7.5 & $4 \%$ \\
\hline Mineral & 8 & $4 \%$ & 4 & $2 \%$ & 2.5 & $1 \%$ & 4.5 & $2 \%$ \\
\hline Matrix & 96.5 & $48 \%$ & 104.5 & 52 & 115 & $58 \%$ & 110.5 & $55 \%$ \\
\hline
\end{tabular}

analyses conducted on the tuyères recovered from the three $200 \mathrm{~kg}$ samples establish the range of formal variation within the Mound A assemblage. Comparisons of mean diameter and bore size (Figure 9) shows a tight clustering within the excavated sample and have respective coefficients of variation of $5 \%$ and $4 \%$. These 'broad' bore tuyères may be indicative of a particular iron technology in Cambodian history and the chronological implications are discussed below.

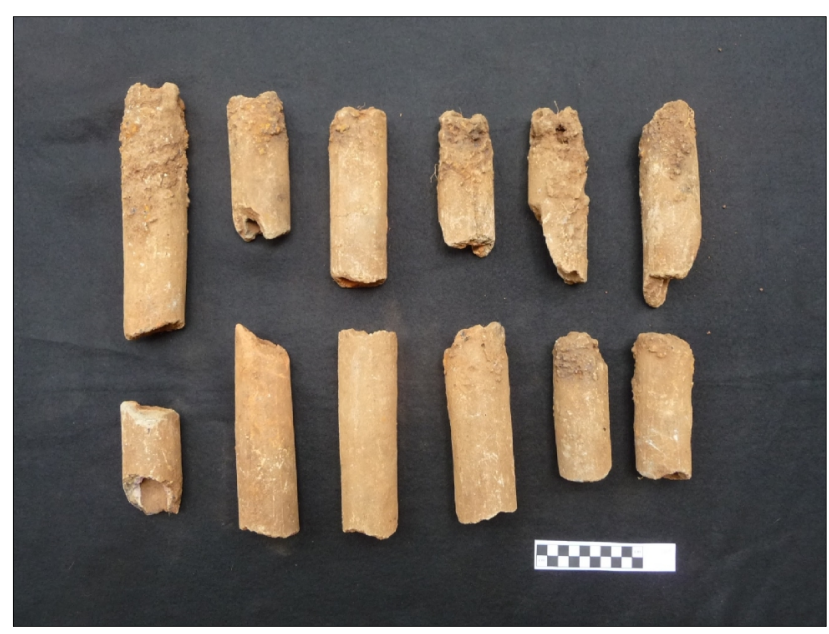

Figure 8. 'Broad' bore tuyères from Trench 1A 1004.

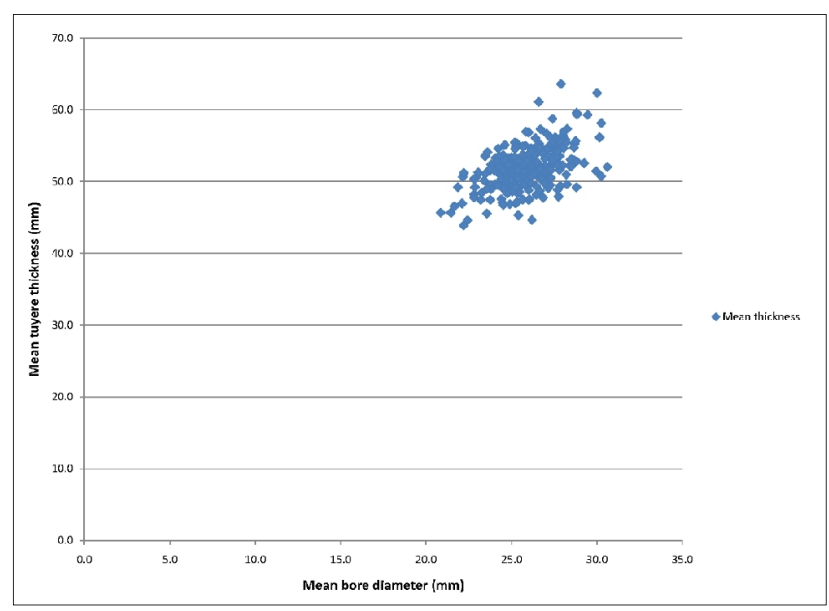

Figure 9. Comparison of mean bore diameter and thickness of tuyères recorded from Trench 1 in Mound A.

\section{CHRONOLOGY OF BOENG KROAM}

The construction date of Boeng Kroam can be inferred from its large, rectilinear form typical of Angkorian period water infrastructure and the shared orientation with Prasat Boeng Sre and the Bakan. Based on these associations the reservoir was likely built sometime between the $10^{\text {th }}$ and $12^{\text {th }}$ centuries. Surface ceramics on top and within its banks similarly indicate activities corresponding to this period while further examination of the roof tiles is necessary to determine whether there was a post-Angkorian occupation phase. Iron production appears to have taken place as several different times during the life history of Boeng Kroam. Location 2 is situated within the bank and therefore either pre-dates the formalisation of the north bank or coincides with its early construction. Locations 1 and 3 are both situated on top of the bank and must post-date its formation. This was corroborated by Trench 2 at Location 1 , which clearly showed that Mound A does not extend into the bank. To determine when the mound was created seven charcoal samples collected from Trench 1 were dated by AMS ${ }^{14} \mathrm{C}$ at the Australian Nuclear Science Technology Organisation (ANSTO) (see Table 2). Comparison of the summed and aggregate probabilities (Figure 10) indicates that that the material in Mound A was deposited during the second quarter of the $15^{\text {th }}$ century. The close clustering of the radiocarbon dates and lack of clear stratigraphic changes suggest that Mound A was the product of shortterm smelting activity, perhaps just a few seasons given the enormous quantities of waste iron smelting can produce. Homogeneity of tuyère measurements from Mound A may therefore act as a proxy for the technological style of iron production practiced during the early $15^{\text {th }}$ century, however, larger samples from well-dated sites are required to confirm this hypothesis.

\section{DISCUSSION: BOENG KROAM AND IMPLICATIONS FOR CAMBODIAN IRON PRODUCTION}

Surveys conducted within Preah Khan confirm that iron production took place at multiple locations between the third and fourth enclosure walls. The distribution of these industrial remains is clearly associated with the banks of trapeang, possibly indicating the need for water during the smelting process for clay preparation or quenching. Boeng Kroam reservoir contains the largest number and most significant slag concentrations at Preah Khan, as well as evidence of occupation and specialised water management 
Table 2. Calibrated AMS results from Boeng Kroam 1 excavation

\begin{tabular}{|c|c|c|c|c|c|c|c|c|c|}
\hline \multirow{3}{*}{$\begin{array}{l}\text { Lab ID } \\
\text { OZM623 }\end{array}$} & \multirow{3}{*}{$\begin{array}{l}\text { Sample ID } \\
\text { INDAP-BK1 }\end{array}$} & \multirow{3}{*}{$\begin{array}{l}\delta^{13} \mathrm{C}(\%) \\
-26.9\end{array}$} & \multirow{3}{*}{$\begin{array}{l}{ }^{14} \mathrm{C} \mathrm{Ag} \\
\text { Mean } \\
460\end{array}$} & \multirow{3}{*}{$\frac{1 \sigma}{35}$} & \multicolumn{4}{|c|}{ Calibrated Age (cal CE) * } & \multirow{3}{*}{$\begin{array}{l}\text { median } \\
1440\end{array}$} \\
\hline & & & & & \multicolumn{2}{|c|}{$1 \sigma$ age range } & \multicolumn{2}{|c|}{$2 \sigma$ age range } & \\
\hline & & & & & 1420 & 1455 & 1405 & 1485 & \\
\hline OZM624 & INDAP-BK8 & -26.6 & 380 & 35 & 1445 & 1620 & 1440 & 1635 & 1510 \\
\hline OZM625 & INDAP-BK11 & -29.1 & 245 & 35 & 1530 & 1955 & 1520 & 1955 & 1660 \\
\hline OZM626 & INDAP-BK12 & -27.4 & 335 & 35 & 1490 & 1635 & 1465 & 1645 & 1560 \\
\hline OZM627 & INDAP-BK13 & -27.1 & 540 & 40 & 1325 & 1430 & 1305 & 1445 & 1400 \\
\hline OZM628 & INDAP-BK14 & -28.5 & 455 & 35 & 1420 & 1455 & 1405 & 1490 & 1440 \\
\hline OZM629 & INDAP-BK15 & -27.2 & 470 & 35 & 1420 & 1450 & 1400 & 1475 & 1435 \\
\hline OZN044 & BK-SL-1003 & -27.7 & 415 & 35 & 1435 & 1610 & 1425 & 1630 & 1470 \\
\hline OZN045 & BK-SL-1006 & -27.0 & 455 & 30 & 1425 & 1455 & 1410 & 1475 & 1440 \\
\hline
\end{tabular}

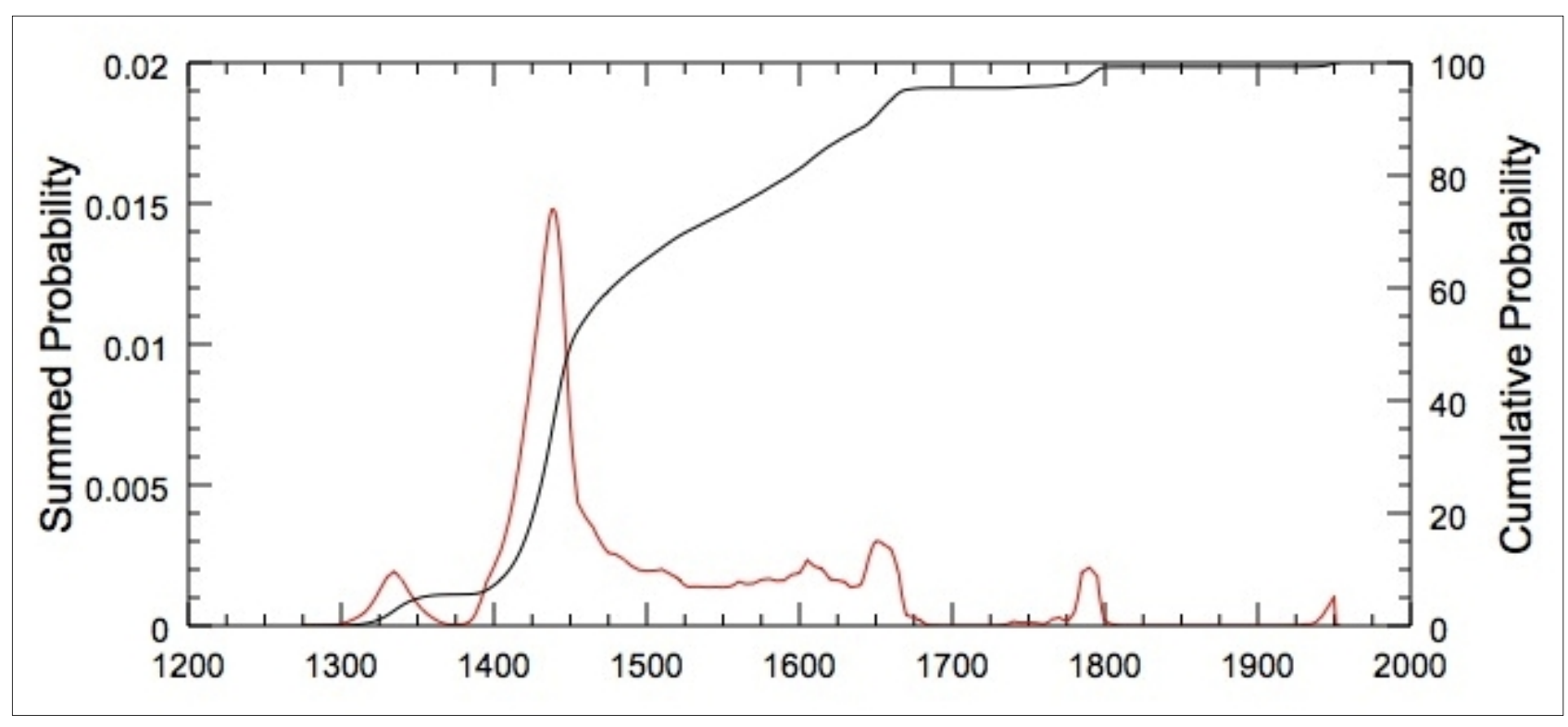

Figure 10. Summed and aggregate probability of seven $A M S{ }^{14} \mathrm{C}$ dates from Trench 1 (image courtesy of C. Cooke).

infrastructure. Based on the excavation at Location 1, Mound $\mathrm{A}$ is a secondary deposition of material from a nearby furnace, possibly located between Mound A and B. Both the homogenous stratigraphy and radiocarbon dating support a short period of iron production at this site. A more signficant result of the radiocarbon dates is that iron smelting activities at Preah Khan took place long after the last masonry structure was completed. This suggests a reuse of the site, which would afford ready access to materials (clay, water) to build the furnace and wood fuel that grew as the reservoir fell into disuse.

Methodologically, we have tested the utility of multiple techniques (topographic survey, geophysical survey, excavation) for investigating slag concentrations in a Cambodian context. Detailed topographic surveys provide important information about the form and extent of the production area. From this data it is possible to quantify the volume of a slag concentration and, with detailed excavation and laboratory-based technological reconstruction data, potentially model the amount of iron produced at the location (Pryce et al. 2014). While GPR transects have successfully documented subsurface features in the Angkor region (see Sonnemann 2010), similar work at Location 1 produced limited results. This problem is can be attributed to the compact nature of the bank characterised by dense clayey soils. Different geophysical methods are now required to effectively map the subsurface extent of slag concentrations. Excavation at Location 1 represented the first subsurface investigation and radiometric dates both within Preah Khan and of a historic period iron production site in Preah Vihear province. Small test trenches are an effective method for identifying the formation process of a slag mound and the collection of samples for dating and technological 
analyses. Area excavation will be needed to investigate in situ furnaces but it should be noted that globally, the actual detection of intact furnace structures is rare. This research has confirmed the presence of iron production at Preah Khan and provided initial results and methods that will help unravel its industrial history. Future investigation will expand on our understanding of local metal production and identify the important part that Preah Khan played within the rise, expansion and collapse of the Khmer Empire.

\section{Acknowledgements}

We would first like to thank the Ministry of Culture and Fine Arts for their collaboration and enabling this research to be conducted at Preah Khan. Support for the field campaigns were obtained from a National Geographic Committee for Research and Exploration Grant and the Australian Research Council Discovery Project (DP0987878). Remote sensing imagery used to create the base map of Preah Khan was provided courtesy of the GeoEye Foundation. Other organisations to be thanked include the Greater Angkor Project (University of Sydney), EFEO Siem Reap and German Apsara Conservation Project. The fieldwork involved a diverse crew including Dan Penny, Christophe Pottier, Kevin Davies, Andrew Wilson, Damian Evans, Heng Nisay, Ea Sanith, Leng Vitou, Khat Srim, and Tiev Vichet. Initial drafts benefitted from the review of Eileen Lustig. Any errors or inconsistencies are solely our own.

\section{BIBLIOGRAPHY}

Aymonier, E. 1900. Le Cambodge: I. Le Royaume Actuel, Volume 1. Paris: Ernest Leroux.

Cœdès, G. 1964. Inscriptions du Cambodge. Volume 7. Hanoi: École Française d'Extrême-Orient.

Cunin, O. 2007. The Bayon: an archaeological and architectural study. In J. Clark (ed.) Bayon: New Perspectives, pp. 138228. River Books: Bangkok.

Delaporte, L. 1999 (1880). Voyage au Cambodge. L'architecture Khmer. Paris: Maisonneuve et Larose.

Groslier, B-P. 1973. Les Inscriptions du Bayon. In Le Bayon, pp. 81-352, EFEO: Paris.

Hendrickson, M. and D. Evans. 2015. Reimagining the City of Fire and Iron: A landscape archaeology of the AngkorPeriod Industrial Complex of Preah Khan of Kompong Svay, Cambodia (ca. 9th to 13th centuries A.D.). Journal of Field Archaeology 40(6):644-664.

Jacques, C. 2007. The Historical Development of Khmer Culture from the Death of Suryavarman II to the 16th century. In J. Clark (ed.), Bayon: New Perspectives, pp. 28-49. River Books: Bangkok.

Jacques, C. and P. Lafond. 2004. L'Empire Khmer. Cités et sanctuaires $V$-XIII siècles. Paris: Fayard.

Kern, H. 1880. Inscriptions cambodgiennes: Inscription de PreaKhan (Kompong Soai), Annales de l'Extrême-Orient 2(23):333-341.

Living Angkor Road Project. 2008. Living Angkor Road Project, Vol. 2008. Nakon Nayok: Chulachomklao Royal Military Academy.
http://larp.crma.ac.th/larp/report/fullreport/RDG50O0003. pdf

Lunet de Lajonquière, É. 1902. Inventaire Descriptif des Monuments du Cambodge, III vols, Volume I. Paris: Ernest Leroux.

Mauger, H. 1939. Prah Khan de Kompon Svay, Bulletin de l'École Française d'Extrême-Orient, 39(2):197-220.

Phann, N. and N. Chrin. 2007. Groupe de Preah Khan (Bakan) de Kampong Svay. In Carte archéologique du Cambodge. $M C B A-E F E O$, ed. Phnom Penh: Commission Nationale du Cambodge pour l'UNESCO.

Pryce, T. O. and S. Natapintu. 2009. Smelting Iron from Laterite: Technical Possibility or Ethnographic Aberration? Asian Perspectives 48:249-264.

Pryce, T.O., Hendrickson, M., Phon, K., Chan, S., Charlton, M.F., Leroy, S., Dillmann, P., Hua, Q., 2014. The Iron Kuay of Cambodia: Tracing the role of peripheral populations in Angkorian to Colonial Cambodia via a 1200 year old industrial landscape. Journal of Archaeological Science 47, $142-163$.

Sharrock, P. 2009. Garuda, Vajrapani and Religious Change in Jayavarman VII's Angkor, Journal of Southeast Asian Studies 40(1):111-151.

Sonnemann, T. 2010. GPR Survey at Prasat Kamnap, Cambodia. Upublished report for the École française d'ExtrêmeOrient: Siem Reap.

Stern, P. 1965. Les monuments Khmers du style du Bayon et Jayavarman VII. Paris: Presses Universitaires de France.

Tissandier, M. A. 1896. Cambodge et Java. Ruines Khmères et Javanaises 1893-1894. Texte et dessins. Paris: G. Masson. 